\title{
Performance Analysis of Photovoltaic Power Generation System
}

\author{
${ }^{1}$ Mergu Chandramouly, ${ }^{2}$ Dr. A. Raghuram \\ 1, 2 Jawaharlal Nehru Technological University, Hyderabad \\ Email:cm.jntuh@gmail.com, raghuram_a@yahoo.co.in
}

Received: $10^{\text {th }}$ Feb 2018, Accepted: 20 $^{\text {th }}$ March 2018, Published: $30^{\text {th }}$ April 2018

\begin{abstract}
This paper presents the Photovoltaic (PV) power generation system for household applications. This proposed system contains solar panels formed by cells. In this system solar cell working principle and its equivalent circuit is presented. Mathematical modeling of PV system is presented and currentvoltage characteristics observed. In this PV model, series and shunt resistance are calculated by efficient iteration method using open circuit voltage. This also provides the theoretical study of PV cell. The proposed system is modeled in MATLAB/ SIMULINK environment. The simulation results show the proposed system is reliable.
\end{abstract}

Keywords: Solar cell, PV System, I-V Characteristics, PV Panel, P-V Characteristics, Modelling of PV system.

\section{Introduction}

Nomenclature:

$\begin{array}{ll}\mathrm{R}_{\mathrm{s}} & \text { Series resistance }(\Omega) \\ \mathrm{R}_{\mathrm{sh}} & \text { Shunt resistance }(\Omega) \\ \mathrm{G} & \text { Irradiance }\left(\mathrm{W} / \mathrm{m}^{2}\right) \\ \mathrm{I}_{0} & \text { Saturation current }(\mathrm{A}) \\ \mathrm{I}_{\mathrm{ph}} & \text { Photoelectric current }(\mathrm{A}) \\ \mathrm{V}_{\mathrm{P}} & \mathrm{PV} \text { voltage }(\mathrm{V}) \\ \mathrm{n} & \text { Number of cells in series } \\ \mathrm{k} & \text { Boltzmann's constant } \\ \mathrm{T} & \text { Temperature }(\mathrm{K}) \\ \mathrm{q} & \text { Electric charge }(\mathrm{C}) \\ \mathrm{I}_{\mathrm{sco}} & \text { Short circuit current }(\mathrm{A}) \\ \mathrm{G} & \text { Irradiation }\left(\mathrm{W} / \mathrm{m}^{2}\right) \\ \mathrm{T} & \text { Temperature }\left({ }^{\circ} \mathrm{C}\right) \\ \mathrm{I}_{1} & \text { Current generated by panel }(\mathrm{A}) \\ \mathrm{I}_{\mathrm{m}} & \text { Current generated by all panels }(\mathrm{A}) \\ \mathrm{P}_{\mathrm{a}} & \text { Power produced by the array }(\mathrm{P}) \\ \mathrm{L} & \text { Inductor }(\mathrm{H}) \\ \mathrm{C} & \text { Capacitor }(\mathrm{F}) \\ \mathrm{R}_{\mathrm{L}} & \text { Load resistor }(\Omega) \\ \mathrm{V}_{0} & \text { Output voltage of the converter }(\mathrm{V}) \\ \mathrm{V}_{\mathrm{dc}} & \text { Input voltage at the converter }(\mathrm{V}) \\ \mathrm{I}_{\mathrm{L}} & \text { Inductor current }(\mathrm{A}) \\ \mathrm{D} & \text { Duty ratio of the converter } \\ & \end{array}$

In this modern world, one cannot assume life without electric power. World population increasing day to day, and to meet the increased population's demand, it is difficult to produce power to them from conventional power generation system. In this case Renewable energy plays an important role to meet electrical power demand. PV systems can absorb the solar power. PV system is the most cost effective, environment friendly natural source for many applications. In isolated areas, it is best suitable for power generation method. The renewable power generation units generally have modular in structure, they can be installed directly at load centers. This type of generation reduces the burden and cost of the power system. The pollution generated by the convention system is also reduces by using the Power from PV systems.

In this work, the basic combination of PV array and different output combinations based on the irradiation change, temperature change are demonstrated. Modeling of PV cell is based on the "Schockely" diode equations. The current-voltage and power-voltage curves are found correct to satisfy the solar cell equations. The Detailed model of PV system is discussed in this paper.

\section{Basics of PV Cell}

A. Operating principle

B. A PV cell produces current, when solar radiation falls on it, as it is a doped material it absorbs the Photon energy. This energy excites the electrons to form as electron hole pair. The recombination of electron hole pairs constitutes the current flow in the closed circuit.

This process continues in solar cell to converts the photon energy into solar energy.

\section{Equivalent circuit}

The solar cell is represented in its acceptable modes as shown.

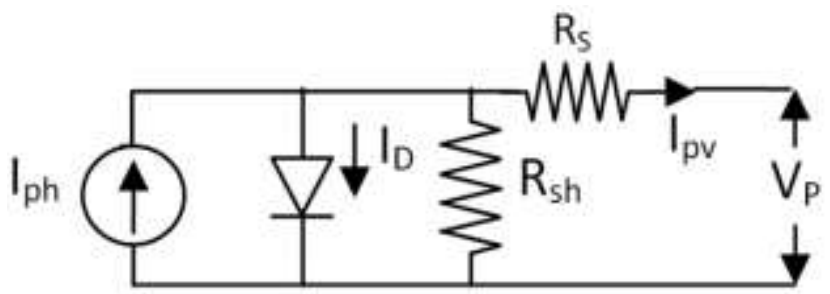

Fig. 2.1 Equivalent circuit of PV cell

Equivalent circuit consists of a current source in parallel with the Diode. A shunt and series resistances connected to this model to control the leakage current. The current generates from this 
model is the resultant of Photon and diode currents. This process is similar to the PN junction diode.

Sun light falls on the solar cell, photon energy from the sun radiation is collected by the cell. This result in direct current flows thought it and varies linearly with the radiation. Without an external resistance the photon current is zero. To develop the current in the circuit, it must be closed loop. The increase in current flow depends on the amount of radiation, temperature of the cell, external resistance etc. By including effects of the shunt and series resistance the model can be improved. The analysis of the equivalent circuit is done by the Kirchhoff's current law. As the law of conservation of charge, energy conversion takes place. This analysis is to develop the current equation for the PV model. The photon current and module current equations developed in mathematical model.

\section{MATHEMATICAL MODEL}

The method to accumulate the sun's energy is by photovoltaic conversion; this conversion of solar energy into electrical energy done by a device called solar cell. A solar cell is doped with several impurities of other chemical elements, and individually they can generate the current from 2 to 4 Amps, at a voltage of 0.46 to $0.48 \mathrm{~V}$. The total direct and diffuse radiation falls on the solar, some of the energy reflects, direct radiation absorbed by the cell converts to electrical energy. The cells are arranged in serial and parallel connections in the solar module.

The solar cell is a current generating source, which generates the current $I_{m}$. The diode current $I_{D}$ flows in opposite direction and is caused by a potential difference between the + and - terminals. In solar cell one resistance is in series $\left(R_{s}\right)$ and one in parallel $\left(\mathrm{R}_{\mathrm{sh}}\right)$, which are represented in the equivalent circuit diagram shown in Fig. 2.1. The series resistance is caused by the fact that a solar cell is not a perfect conductor. The parallel resistance is caused by leakage of current from one terminal to the other due to poor insulation. For an ideal solar cell, $R_{s}=0$ and $R_{s h}=\infty$. The equation describes the model, where the relating output current and voltage of a PV module at irradiance ' $G$ ' can be given as

$$
I_{m}=I_{p h}-I_{0}\left[\exp \left(\frac{V_{p}+R_{s} I_{m}}{A}\right)-1\right]-\left[\frac{V_{p}+R_{s} I_{m}}{R_{s h}}\right]
$$

$\mathrm{A}=\frac{\mathrm{nkT}}{\mathrm{q}}$
The photovoltaic current is obtained as

$$
\mathrm{I}_{\mathrm{ph}}=\mathrm{I}_{\mathrm{sco}}\left(\frac{\mathrm{G}}{\mathrm{G}_{0}}\right)\left(1+\alpha_{1}\left(\mathrm{~T}-\mathrm{T}_{0}\right)\right) \frac{\mathrm{R}_{\mathrm{s}}+\mathrm{R}_{\mathrm{p}}}{\mathrm{R}_{\mathrm{sh}}}
$$

(3) The specifications of the module at standard test conditions are given in Table-1.

Table - 1: PV Specifications at $1000 \mathrm{~W} / \mathrm{m}^{2}$ and $25^{\circ} \mathrm{C}$

\begin{tabular}{|l|l|}
\hline PV Power & $160 \mathrm{~W}$ \\
\hline Open Circuit Voltage & $43.2 \mathrm{~V}$ \\
\hline Short Circuit Current & $8.21 \mathrm{~A}$ \\
\hline Nominal Voltage & $39.3 \mathrm{~V}$ \\
\hline Nominal Current & $4.4 \mathrm{~A}$ \\
\hline
\end{tabular}

\section{FORMATION OF THE SOLAR PANEL}

Solar panel consists of solar cells connected in series or parallel in order to achieve the required rating of the panel.

In serial connections the voltage is sum up, and in parallel connections currents gets added. The type of connections may increase or decrease the ratings of $\mathrm{V}$ and I without changing the power rating of the panel. The arrangement of solar cells in the solar power system is as follows: Group of Solar cells forms the solar panel and these panels connected to become a module. All modules are connected in such a way to form an array of the solar power system.

The solar panel formed by the primary connections of the cells, which in addition to increase the rating of the panel. In small power applications we use solar panel installed at our convenient places. For DC power applications directly uses the solar panels in houses. The arrangement of solar panels in a power system made to increase the rating of the power system.

Fig.4.1 shows the formation of a single solar PV Panel from modules and modules from solar cells. Solar cells with open circuit voltage of $0.6 \mathrm{~V}$ and short circuit current of $1 \mathrm{~A}$ is considered. Six numbers of solar cells of each $0.6 \mathrm{~V}$ are connected in series to form a solar module. Now, this module is with rating of $3.6 \mathrm{~V}$ and $1 \mathrm{~A}$. The rated voltage is $43.2 \mathrm{~V}$, in order to achieve this rated voltage, 12 modules are connected in series to get the required specifications. Here in the below figure, 6 modules are showing, in every module again there are two bunches of each 6 cells connected in series. 


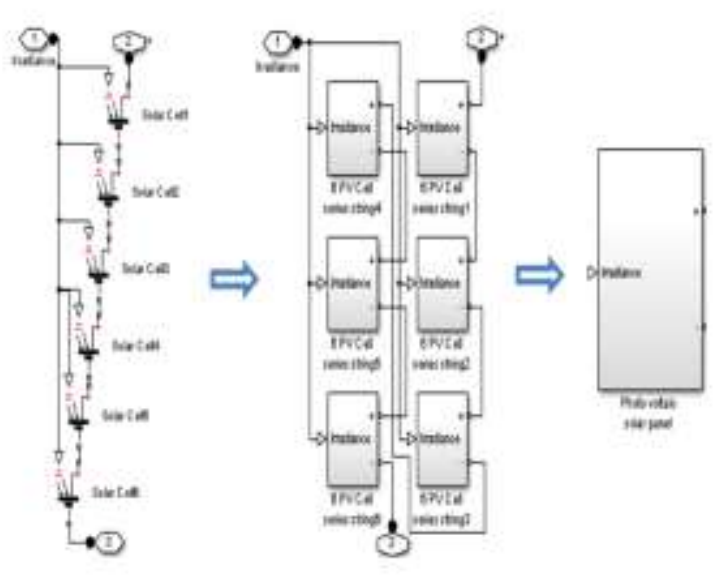

Fig. 4.1 Formation of Solar panel

\section{PERFORMANCE CHARACTERISTICS}

The performance characteristics are of solar panel is of current- voltage and power -voltage curves. This was chive by the simulation of panel in Matlab/Simulink software. Now, the solar panel obtained in Fig.4.1 is used for simulation.

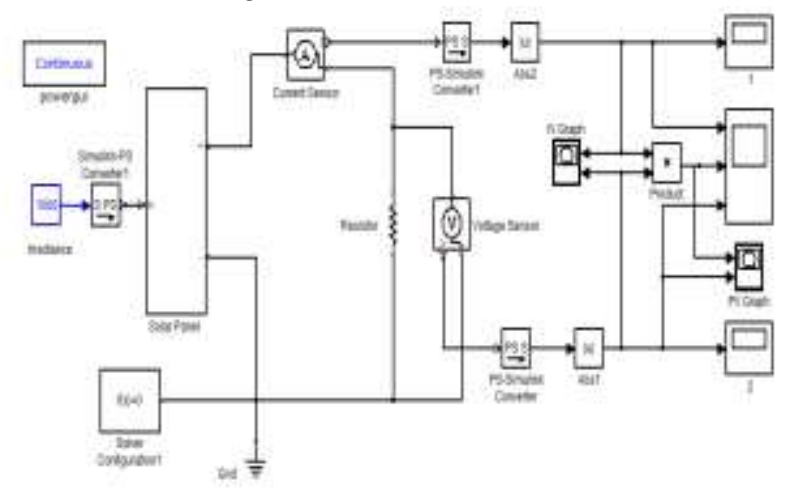

Fig 5.1 simulation model of PV cell

The total solar panel is subjected to different irradiations and different temperature, in order to know its performance characteristics. Fig.5.1 shows the simulation model of the Solar PV panel. All the cells are connected in serial mane to develop the $43.2 \mathrm{~V}$ of the system. There are 72 cells of each having open circuit voltage of $0.6 \mathrm{~V}$.

To obtain the I-V curves of the system, current and voltage measurements connected to the panel. These measurements are of Simscape library models, to connect with the simulink environment PS-S block is needed. PS-S blocks coverts Physical signals to Simulink, S-PS blocks vice versa. From the measurements, it was observed that the solar panel current voltage relations were found satisfactory with the developed equations. Powervoltage curves also verified with the software.
In this model the developed power may be used for DC power applications or to store in battery for further usage. This system is best suitable for small DC power applications.

\section{A. Simulation results}

The performance characteristics of Solar PV panel are done by using MATLAB/Simulink for different irradiation and different temperatures. The simulation of the PV panel is done for irradiation of $1000 \mathrm{Watts} / \mathrm{m}^{2}$ and temperature of $25^{\circ} \mathrm{C}$. The output curves as shown in the below figures.

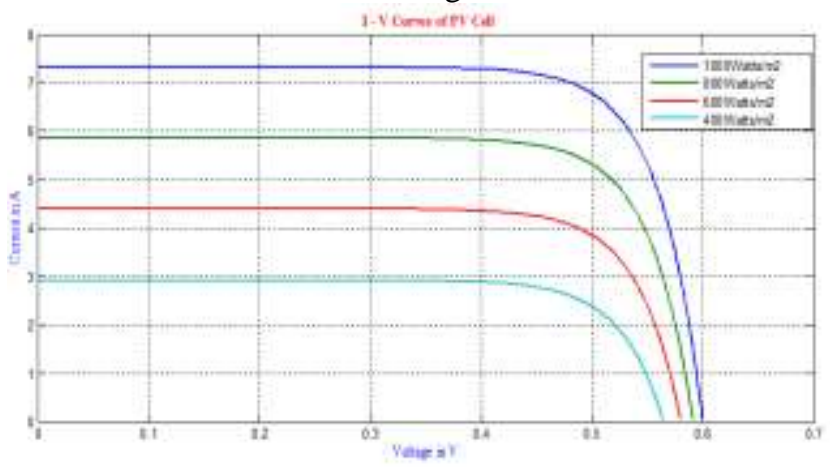

Fig 5.2 Output waveforms of $I-V$ and $P-V$ curves for Temperature $25^{\circ} \mathrm{C}$ and irradiance of 1000Watts $/ \mathrm{m}^{2}$

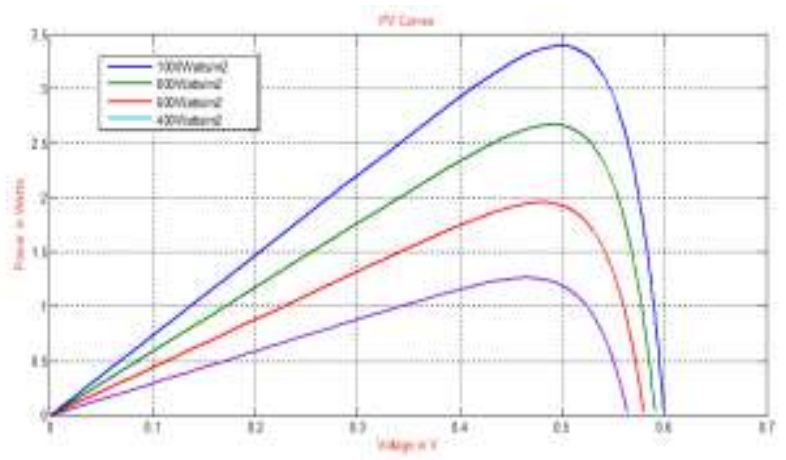

Fig 5.3 I-V and P-V curves for Temperature $25^{\circ} \mathrm{C}$ and irradiance of 800 Watts $/ \mathrm{m}^{2}$

From the above Fig. 5.2, it is observed that with no current flowing in the panel there is voltage called open circuit voltage. Also for zero voltage condition, there exists a Short circuit current.

Fig 5.2 and fig 5.3 are obtained with same temperature for different irradiations of $1000 \mathrm{Watts} / \mathrm{m}^{2}$ and 800 watts $/ \mathrm{m}^{2}$. It is observed that as the irradiation increases the power conversion efficiency of the panel increases. For more irradiation we will get more power. Similarly there is a temperature effect is also considered on the panel.

\section{B. Energy Storage}

Solar System uses the battery for storage of energy. Storage elements improve the system reliability. The rating of the battery depends on our load. All the DC power operated devices connected this battery directly. It is best practice to use for isolated PV generating systems. 


\section{Inverter}

PV systems generate DC power. If the load is an AC power operated load, it is necessary to use an Inverter to supply the load.

\section{Conclusion}

In this paper, performance of the Solar panel is simulated and it is found satisfactory. The theoretical explanation of PV panel formation is also presented. Current-Voltage characteristics of the PV panel found satisfactory with the design. The design is based on the mathematical equations with varying irradiation and temperature is presented. For the change of irradiation there is a corresponding change in its output. The PV system is best suitable for small DC power applications. The performance characteristics of PV panel were tested through Matlab/Simulink software.

\section{References}

[1] H. B. Vika, "Modelling of Photovoltaic Modules with Battery EnergyStorage in Simulink/Matlab," June (2014) Trondheim Norwegian University of Science and Technology.

[2] J. A. Ramos-Hernanz, J. J. Campayo, J. Larranaga, E. Zulueta, O. Barambones, J. Motrico, U. F. Gamiz and I. Zamora, "Two photovoltaic cell simulation models in matlab/simulink," International Journal on "Technical and Physical Problems of Engineering (IJTPE), " Iss. 10, Vol. 4, No. 1, Mar. 2012

[3] Mohibullah, Imdadullah and Ashraf; "Estimation of $\mathrm{CO}_{2}$ Mitigation Potential through Renewable Energy Generation"; IEEE conference on Power and Energy, pp.24 - 29, 2006.

[4] Sousa. J and Martins. A; “Optimal renewable generation mix of hydro, wind and photovoltaic for integration into the Portuguese power system"; pp. $1-6,2013$

[5] Sree. B., Ramaprabha. R. and Mathur. B. L.; "Modeling and controlling of standalone solar photovoltaic charge system"; Emerging Trends in Electrical and Computer Technology (ICETECT), pp.78-81, 2011.

[6] Sanjeeva Reddy. B. R., Jambholkar. P., Badari Narayana and Srinivasa Reddy; "MPPT A logarithm Implementation for Solar Photovoltaic Module Using Microcontroller"; India Conference (INDICON); pp.1-3; 2011

[7] Koutroulis. E., Blaabjerg. F.,;"A new technique for tracking the global maximum power point of PV arrays operating under partial - shading conditions", IEEE Photovoltaic's, pp. 184-190, 2012.

[8] Gomes. M. A., Galotto Jr., L., Sampaio. L., Melo. A., Canesin. C. A.; "Evaluation of the main MPPT techniques for photovoltaic applications", IEEE Transactions Industrial Electronics, pp.1156 - 1167, 2013.

[9] Kashif. M. F., Sehwa Choi, Yongsoon Park, Seung - Ki Sul; "Maximum power point tracking for single stage grid-connected PV system under partial shading conditions"; $; 7^{\text {th }}$ International Power Electronics and Motion Control Conference (IPEMC),Vol.2, pp.1377 1383, 2012.

[10] Veerachary. M., Senjyu. T., and Uezato K.; "Neural network - based maximum PowerPoint tracking of coupled - inductor interleaved boost converter supplied PV system using fuzzy controller"; Transactions Industrial Electronics, pp.749-758, 2003. 